EDITORIAL

http://dx.doi.org/10.4314/mcd.v11i2.7

\section{Approaching the limits}

\author{
"A committee is a group that keeps minutes and loses hours." \\ - Milton Berle
}

From the 4th - 17th December 2016, the parties of the Convention for Biodiversity held their 13th conference in Cancún, Mexico. At the event, a revised red list was produced. On the list are some species featured for the first time. Others were downlisted, or moved into categories more dire than previously was the case.

This convention - along with others of a similar nature should not be viewed as tools fashioned to improve the current situation: more accurately, these conventions serve as an index of sorts, there to follow the ongoing decrease of biodiversity. In reality, very few recommendations presented and accepted during these conferences, are ever followed through by means of any effective actions. This lack of action plans being implemented is often ascribed to other 'more pressing' priorities.

A noteworthy perspective not taking into account any specific countries, politicians or NGOs, is that of human demography. It is estimated that Homo sapiens is some 200,000 years old. While it is impossible to know the population of the species' founding stock, we might say that it took [200,000 years minus 200 years] for the population to reach the one billion mark, globally speaking. Effectively, it means that this figure was reached by the year 1800 . Some two centuries later, by 2011, the world's human population totalled seven billion (Roberts 2011). Whatever the criteria may be, it has to be said that this is impressive. During my own lifetime, the human population has already multiplied by three.

Simultaneously, we are only too aware of a great many species whose global populations are estimated to have declined by more than $90 \%$ of their known numbers (Kolbert 2014). What will happen next? Where is this leading to? Nobody really knows. However, a few comments may be worth consideration. In ecology and in epidemiology, certain phenomena can only occur above certain thresholds, like population density or population quantity. In the case of human beings, we may soon be facing situations where new possibilities of diffusion, be it of microorganisms, genes, or of any risk factor, will become a reality (Quammen 2012, Moutou and Pastoret 2015). In the case of non-human species, we may increasingly witness the consequences of the Allee effect, where a population drops below the size required for it to function normally. This leads to an increased probability of the species' extinction, regardless of the cause of the death of its last member (Courchamp et al. 2008).

I would add one more comment. For millennia, we never gave thought to - nor envisioned, the limits of our planet and finite nature of our resources. Now however, we find we are facing a horizon which is no longer moving away or retreating as we keep on advancing. Many scientists have cautioned that, close to these limits, the global laws and theorems lose validity. If this is right, maybe we are left with one last chance. The window of time in which to seize this eventuality, may be very short. Let us hope we will not miss it.

\author{
François Moutou \\ French Mammal Society \\ France \\ Email: francoismoutou@orange.fr
}

\section{REFERENCES}

Courchamp, F., Berec, L. and Gascoigne, J. 2008. Allee Effects in Ecology and Conservation. Oxford University Press, Oxford, New York. (doi:10.1093/acprof:oso/9780198570301.001.0001)

Kolbert, E. 2014. The Sixth Extinction - An Unnatural History. Henry Holt and Company, New York.

Moutou, F. and Pastoret, P.-P. 2015. Defining an emerging disease. Scientific and Technical Review of the Office International des Epizooties 34, 1: 41-44. Available at <http://web.oie.int/boutique/extrait/04moutou4548fr.pdf>

Quammen, D. 2012. Spillover. Animal Infections and the Next Human Pandemic. W. W. Norton \& Company. New York, London.

Roberts, L. 2011.9 billion? Science 333: 540-543. (doi:10.1126/science.333.6042.540) 


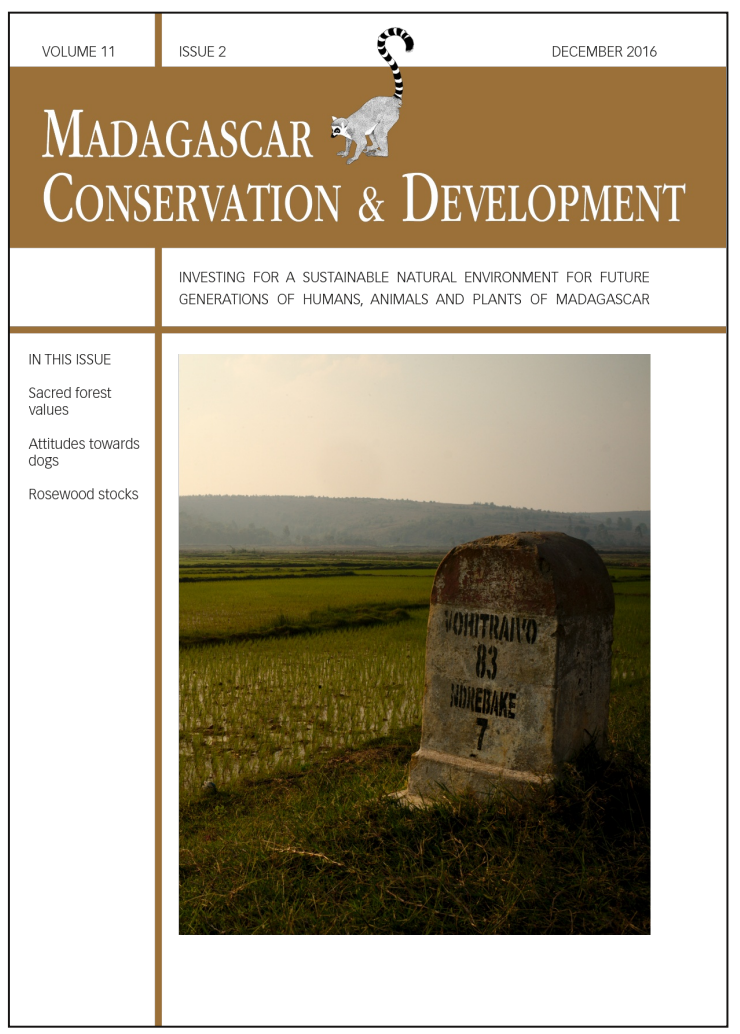

Madagascar Conservation \& Development is the journal of Indian Ocean e-Ink. It is produced under the responsibility of this institution. The views expressed in contributions to MCD are solely those of the authors and not those of the journal editors or the publisher.

All the Issues and articles are freely available at http://www.journalmcd.com

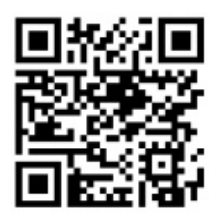

Contact Journal MCD

info@journalmcd.net for general inquiries regarding MCD funding@journalmcd.net to support the journal

Madagascar Conservation \& Development Institute and Museum of Anthropology

University of Zurich

Winterthurerstrasse 190

$\mathrm{CH}-8057$ Zurich

Switzerland

Indian Ocean e-Ink

Promoting African Publishing and Education

www.ioeink.com

Missouri Botanical Garden (MBG)

Madagascar Research and Conservation Program BP 3391

Antananarivo, 101, Madagascar 